Article

\title{
Eckol Inhibits Particulate Matter 2.5-Induced Skin Keratinocyte Damage via MAPK Signaling Pathway
}

\author{
Ao Xuan Zhen ${ }^{1,+}$, Yu Jae Hyun ${ }^{1,+}{ }^{+}$, Mei Jing Piao ${ }^{1}$, Pincha Devage Sameera Madushan Fernando ${ }^{1}$, \\ Kyoung Ah Kang ${ }^{1}$, Mee Jung Ahn ${ }^{2}$, Joo Mi Yi ${ }^{3}$, Hee Kyoung Kang ${ }^{1}$, Young Sang Koh ${ }^{1}$, \\ Nam Ho Lee ${ }^{4}$ and Jin Won Hyun ${ }^{1, *(D)}$ \\ 1 School of Medicine, Jeju National University, Jeju 63243, Korea \\ 2 Laboratory of Veterinary Anatomy, College of Veterinary Medicine, Jeju National University, \\ Jeju 63243, Korea \\ 3 Department of Microbiology and Immunology, College of Medicine, Inje University, Busan 47392, Korea \\ 4 Department of Chemistry and Cosmetics, College of Natural Sciences, Jeju National University, \\ Jeju 63243, Korea \\ * Correspondence: jinwonh@jejunu.ac.kr; Tel.: +82-64-754-3838; Fax: +82-64-702-2687 \\ + These two authors contributed equally to this study.
}

Received: 1 July 2019; Accepted: 25 July 2019; Published: 27 July 2019

\begin{abstract}
Toxicity of particulate matter (PM) towards the epidermis has been well established in many epidemiological studies. It is manifested in cancer, aging, and skin damage. In this study, we aimed to show the mechanism underlying the protective effects of eckol, a phlorotannin isolated from brown seaweed, on human $\mathrm{HaCaT}$ keratinocytes against $\mathrm{PM}_{2.5}$-induced cell damage. First, to elucidate the underlying mechanism of toxicity of $\mathrm{PM}_{2.5}$, we checked the reactive oxygen species (ROS) level, which contributed significantly to cell damage. Experimental data indicate that excessive ROS caused damage to lipids, proteins, and DNA and induced mitochondrial dysfunction. Furthermore, eckol $(30 \mu \mathrm{M})$ decreased ROS generation, ensuring the stability of molecules, and maintaining a steady mitochondrial state. The western blot analysis showed that $\mathrm{PM}_{2.5}$ promoted apoptosis-related protein levels and activated MAPK signaling pathway, whereas eckol protected cells from apoptosis by inhibiting MAPK signaling pathway. This was further reinforced by detailed investigations using MAPK inhibitors. Thus, our results demonstrated that inhibition of $\mathrm{PM}_{2.5}$-induced cell apoptosis by eckol was through MAPK signaling pathway. In conclusion, eckol could protect skin HaCaT cells from $\mathrm{PM}_{2.5}$-induced apoptosis via inhibiting ROS generation.
\end{abstract}

Keywords: phlorotannin; particulate matter; reactive oxygen species; keratinocytes

\section{Introduction}

Natural compounds can be effective candidates for various skin diseases. Particularly, phlorotannins extracted from seaweeds have interesting properties that make them useful for cosmeceutical applications. They can whiten the skin by inhibiting melanin synthesis [1], and delay skin wrinkles by inhibiting matrix metalloproteinase [2]. Moreover, phlorotannins show antioxidant [3], anti-inflammatory [4], and hair-growth promotion activities [5]. Studies have shown that eckol, which is a kind of phlorotannin present in brown seaweeds (Phaeophyceae), decreases

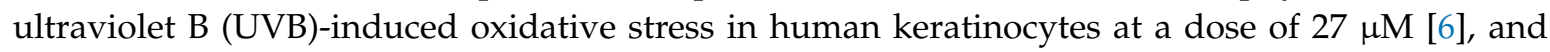
inhibits cancer in SKH-1 mice via inhibiting UVB-induced inflammation [7], and declines matrix metalloproteinase-1 level in human dermal fibroblasts implying anti-aging effects at a dose of $10 \mu \mathrm{M}$ [8]. Our earlier studies have proved that eckol could clear excess reactive oxygen species (ROS) and protect skin keratinocytes from apoptosis [6]. 
Air pollution by continuous emission of various pollutants into the atmosphere has led to the rapid decline of public health and accelerated climate change [9]. In addition, more than $90 \%$ population in the world breathed unhealthy air in 2017, which suggests that particulate pollution is a global challenge [10]. According to previous studies, particulate matter (PM) increases the public health risks for various diseases, such as respiratory disease [11], cardiovascular disease [12], and lung inflammation [13]. Fine particulate matter with a diameter less than $2.5 \mu \mathrm{m}$, denoted as $\mathrm{PM}_{2.5}$, is present in the air for over several hours to weeks [14]. Significantly, $\mathrm{PM}_{2.5}$ could deeply penetrate the skin and the respiratory tract [15]. Skin damage caused by $\mathrm{PM}_{2.5}$ is manifested as inflammatory skin diseases, such as atopic dermatitis, acne, and psoriasis, aging, and cancer via multiple signaling pathways [16].

A recent study presents a comprehensive summary of the characteristics of eckol relevant for its therapeutic potential, including antioxidant activity following exposure to $\mathrm{H}_{2} \mathrm{O}_{2}$, radiation, and $\mathrm{PM}$ [17]. $\mathrm{PM}_{2.5}$ is a fine particulate matter that causes skin apoptosis related to the ROS generation [16], and it would be interesting to investigate whether eckol protected skin cells from ROS-induced damage. Moreover, the mode of action of eckol on $\mathrm{PM}_{2.5}$ is not well-established. Here, we have investigated the potential benefits of eckol on keratinocytes by studying its inhibitory effect on molecular damage, mitochondrial dysfunction, apoptosis-related factors, and MAPK signaling related proteins. In this study, our aim was also to gain insights into the mechanism underlying the protective action of eckol on $\mathrm{PM}_{2.5}$-induced skin cell apoptosis.

\section{Results}

\subsection{Eckol Showed Anti-oxidative Effects to Protect Cells from PM 2.5-Induced Apoptotic Cell Death}

Previous studies have shown that eckol exhibited no cytotoxicity to HaCaT cells at a concentration of $30 \mu \mathrm{M}$ [18] but showed antioxidant activity [6]. Therefore, in this study, we used $30 \mu \mathrm{M}$ of eckol (Figure 1a) as the optimal concentration. From Figure $1 \mathrm{~b}, \mathrm{c}$, it is evident that while $\mathrm{PM}_{2.5}$ increased the levels of ROS as indicated by $2^{\prime}, 7^{\prime}$-dichlorofluorescein diacetate (DCF-DA) staining, eckol inhibited intracellular ROS generation. The results demonstrated that $\mathrm{PM}_{2.5}$-induced ROS could accelerate cell apoptosis and death. To confirm that eckol could help cells escape from this damage, we checked nuclei integrity, and cell viability. According to results, $\mathrm{PM}_{2.5}$ treatment led to sub- $\mathrm{G}_{1}$ cell population after $24 \mathrm{~h}$ (Figure 1d), fragmented nuclei (Figure 1e), and cell death (Figure 1f). However, it was noted that following treatment with eckol, the apoptotic cell death was decreased, and the cell viability was also enhanced. 
<smiles>Oc1cc(O)cc(Oc2c(O)cc(O)c3c2Oc2c(O)cc(O)cc2O3)c1</smiles>

(a)

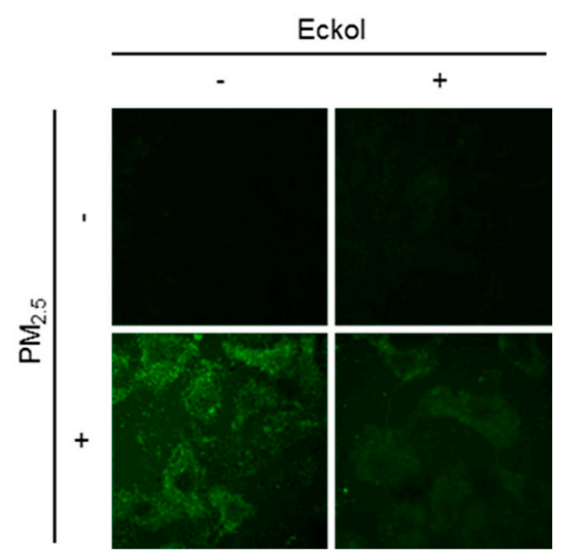

(c)
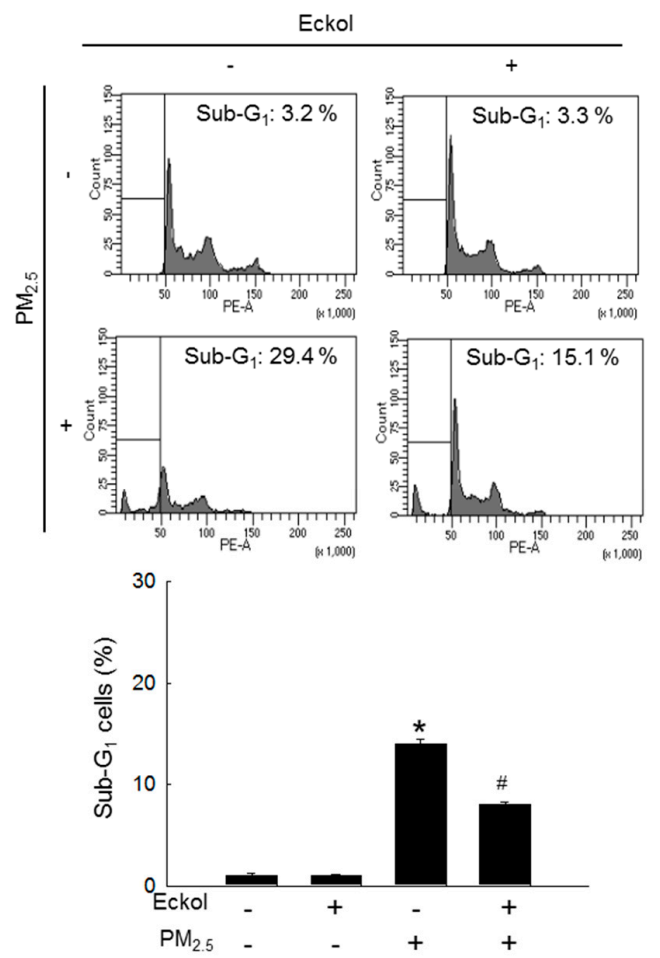

(d)
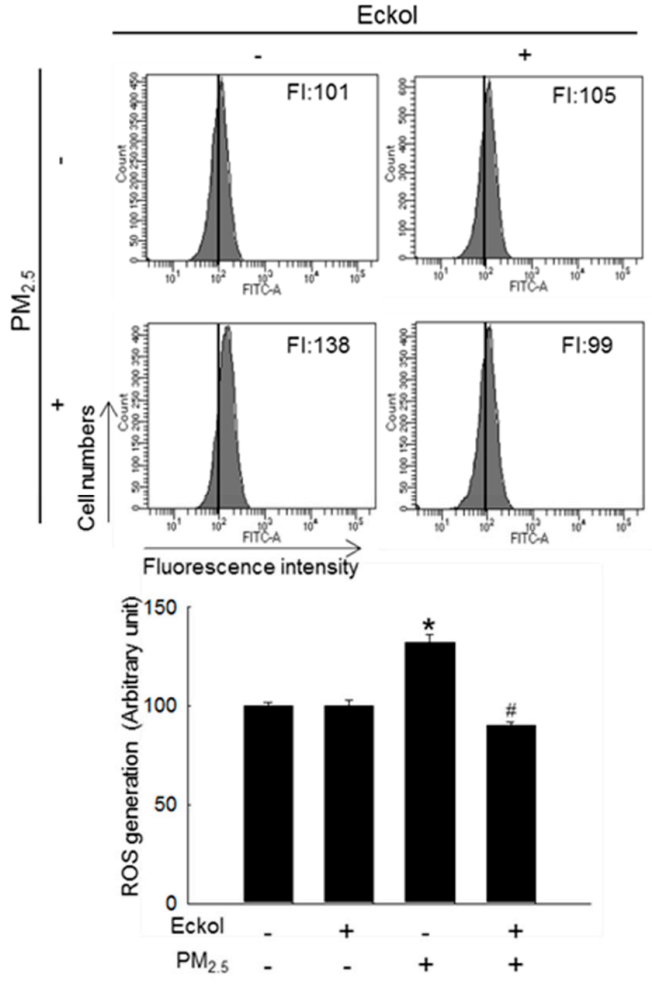

(b)
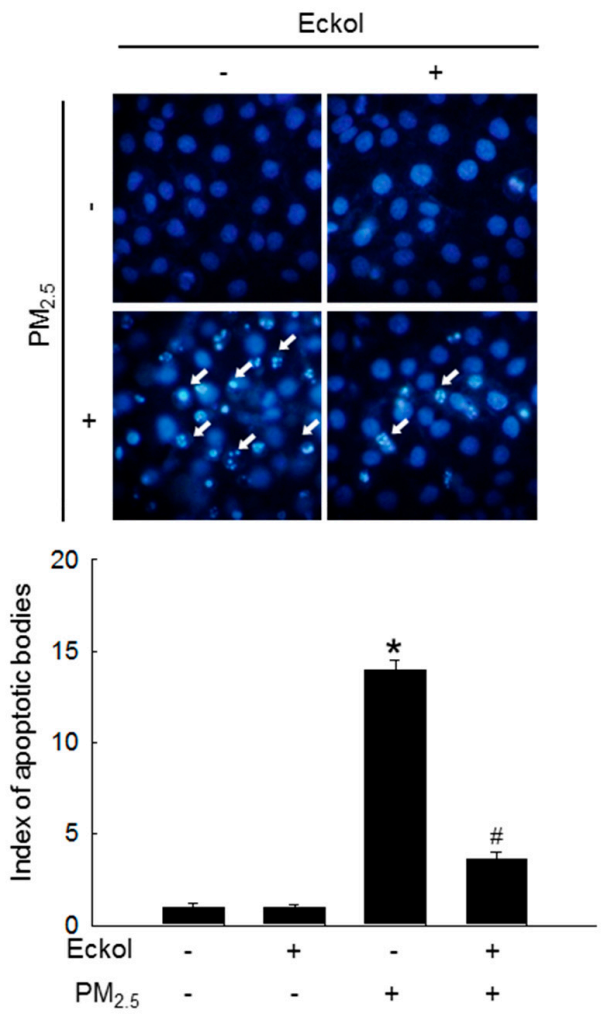

(e)

Figure 1. Cont. 

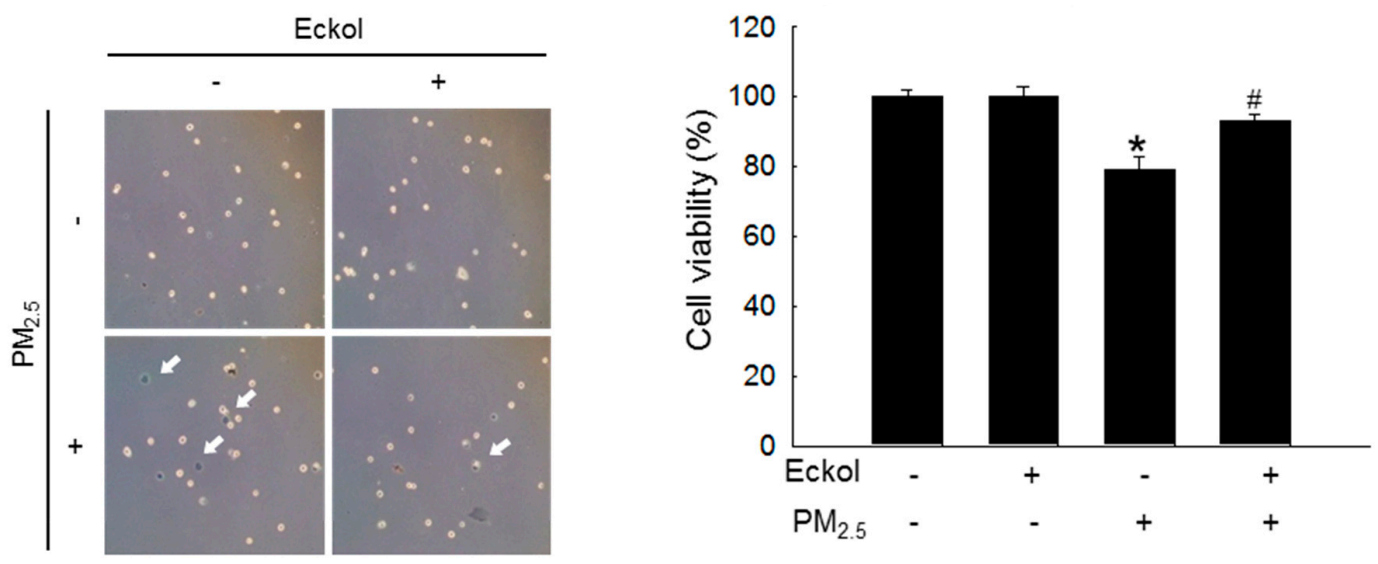

(f)

Figure 1. Eckol $(30 \mu \mathrm{M})$ decreased cell apoptotic bodies by inhibiting $\mathrm{PM}_{2.5}$-induced ROS level. (a) Chemical structure of eckol. Intracellular ROS level (DCF-DA staining) induced by $\mathrm{PM}_{2.5}(50 \mu \mathrm{g} / \mathrm{mL})$ was inhibited via treatment with eckol as observed by (b) flow cytometry and (c) confocal. (d) Sub-G cell population induced by $\mathrm{PM}_{2.5}$ was blocked by treatment with eckol, as determined by propidium iodide staining. (e) Apoptosis induced by $\mathrm{PM}_{2.5}$ was reduced by treatment with eckol, observed by Hoechst 33342 staining. The arrow indicated the apoptotic bodies. (f) Cell deaths induced by $\mathrm{PM}_{2.5}$ were reduced via treatment with eckol, determined by trypan blue assay. The arrow indicated the dead cell (stained cells by trypan blue). All experiments were performed after treatment with $\mathrm{PM}_{2.5}$ for 24 $\mathrm{h}$, and $n=3$ for every group. ${ }^{*} p<0.05$ and ${ }^{\#} p<0.05$ compared to control cells and $\mathrm{PM}_{2.5}$-exposed cells, respectively.

\subsection{Eckol Protected Cells against $P M_{2.5}$-Induced Intracellular Molecular Damage}

Previous studies have shown that increment in ROS disrupted intracellular molecules involved in apoptosis $[19,20]$. Thus, we detected lipid peroxidation, protein carbonylation, and DNA damage. The confocal images show that $\mathrm{PM}_{2.5}$ caused generation of phosphine oxide, which is a marker of lipid peroxidation. However, this was reversed by treatment with eckol (Figure 2a). Moreover, $\mathrm{PM}_{2.5}$ aggravated protein carbonylation level, which was decreased by eckol treatment (Figure 2b). DNA lesions and strand breaks were studied by staining the cells with avidin-tetramethylrhodamine isothiocyanate (TRITC) conjugate (Figure 2c) and comet assay (Figure 2d). The data show that eckol guarded DNA against $\mathrm{PM}_{2.5}$.

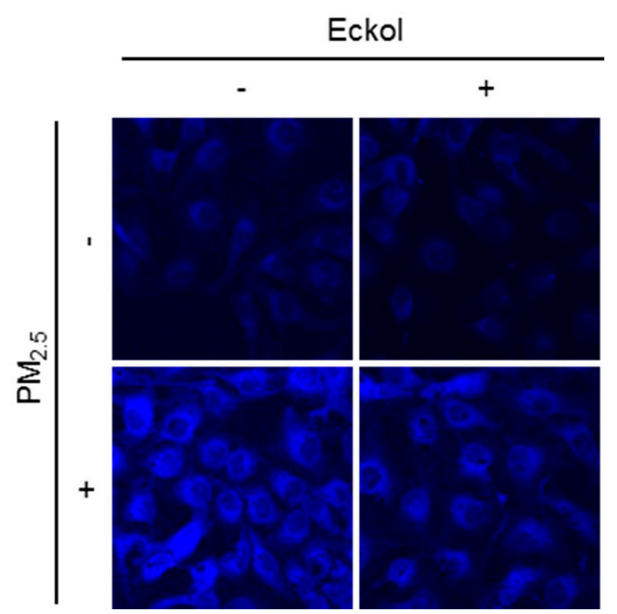

(a)

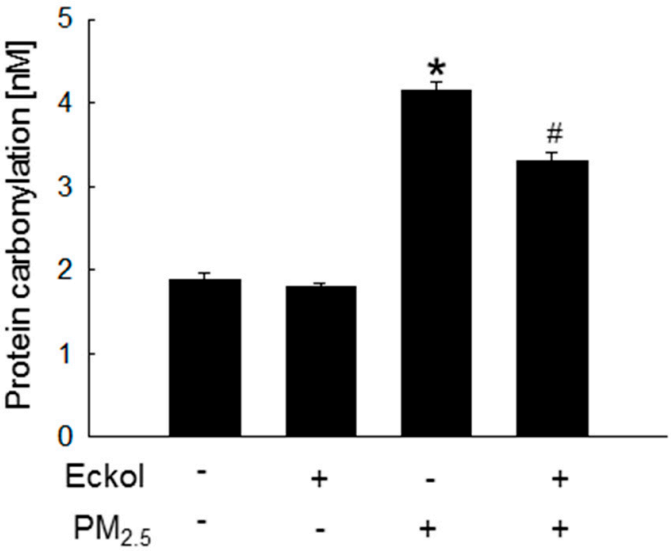

(b)

Figure 2. Cont. 


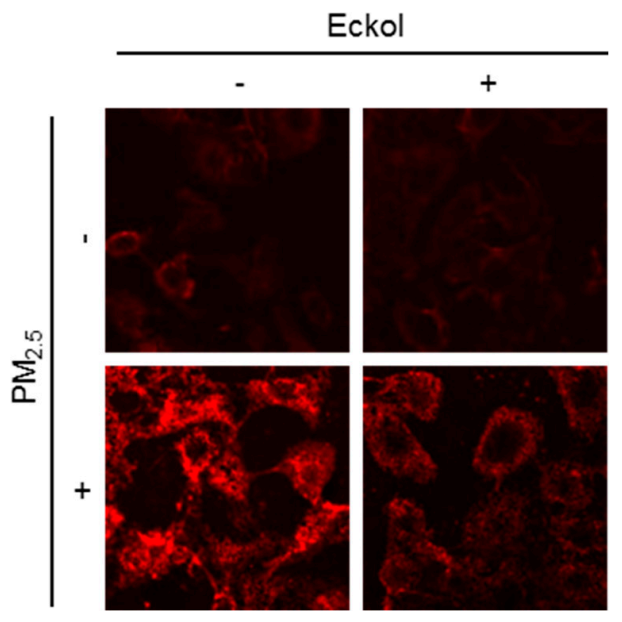

(c)



(d)

Figure 2. Eckol $(30 \mu \mathrm{M})$ protected intracellular molecules from $\mathrm{PM}_{2.5}$-induced damage. (a) Lipid oxidation induced by $\mathrm{PM}_{2.5}$ was mitigated via treatment with eckol through diphenylpyrenylphosphine (DPPP) staining. (b) Protein carbonylation induced by $\mathrm{PM}_{2.5}$ was declined via treatment with eckol as observed by a protein carbonylation assay. DNA damage induced by $\mathrm{PM}_{2.5}$ was inhibited via treatment with eckol, as confirmed through (c) avidin-TRITC staining and (d) comet assay. All experiments were performed after treatment with $\mathrm{PM}_{2.5}$ for $24 \mathrm{~h}$, and $\mathrm{n}=3$ for every group. ${ }^{*} p<0.05$ and $\# p<0.05$ compared to control cells and $\mathrm{PM}_{2.5}$-exposed cells, respectively.

\subsection{Eckol Prevented $P M_{2.5}$-Induced Mitochondrial Dysfunction}

Mitochondria play an important role in cellular energy production, and their biogenesis is related to synthesis of molecules, such as lipids and proteins, DNA transcription, and even cell apoptosis [21]. Next, we examined mitochondrial functions. Dihydrorhodamine 123 (DHR123) staining images show that mitochondrial ROS was accumulated in $\mathrm{PM}_{2.5}$-treated group. Whereas, ROS level was decreased by pretreatment with eckol (Figure 3a). Both flow cytometry (Figure 3b) and confocal microscopy (Figure 3c) data demonstrate that $\mathrm{PM}_{2.5}$ caused mitochondrial depolarization, which was arrested by treatment with eckol. Furthermore, the flux of mitochondrial calcium was increased in the $\mathrm{PM}_{2.5}$-treatment group, and it was decreased in eckol-treatment group, which was monitored using the calcium indicator, Rhod-2 acetoxymethyl ester (Rhod-2 AM), by confocal microscopy (Figure 3d) and flow cytometry (Figure 3e). 


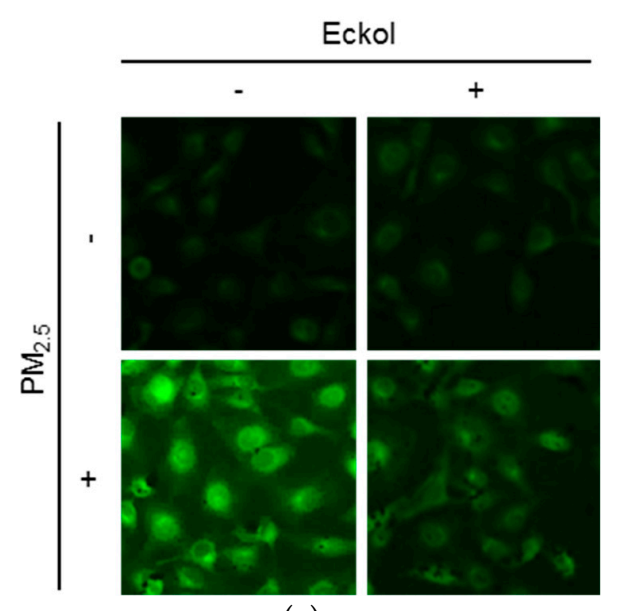

(a)

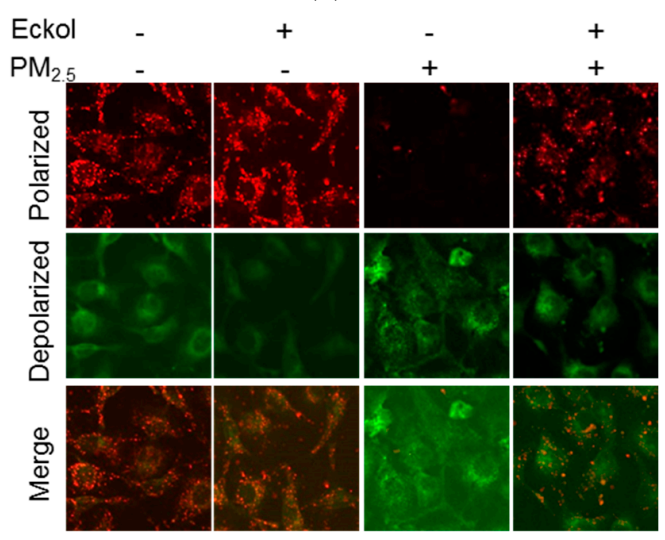

(c)



(d)

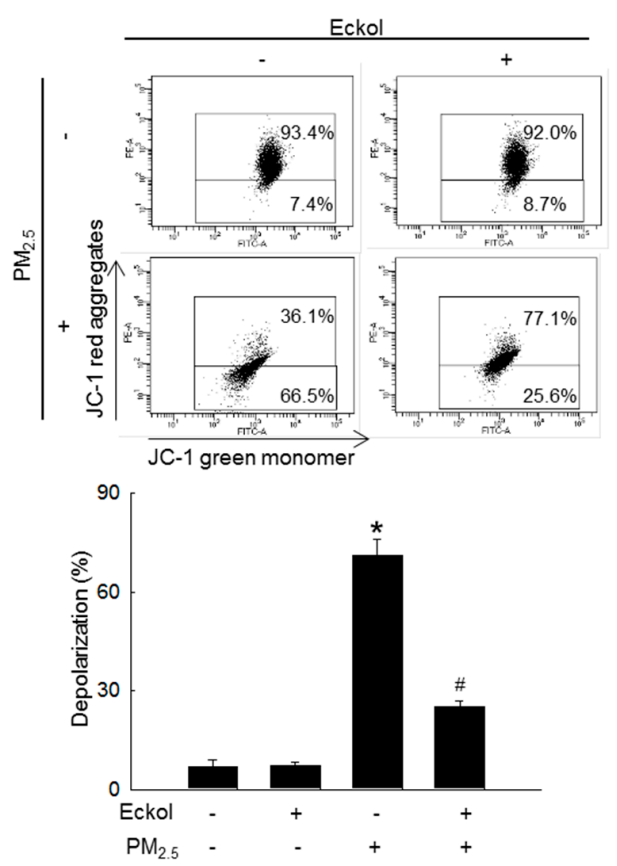

(b)
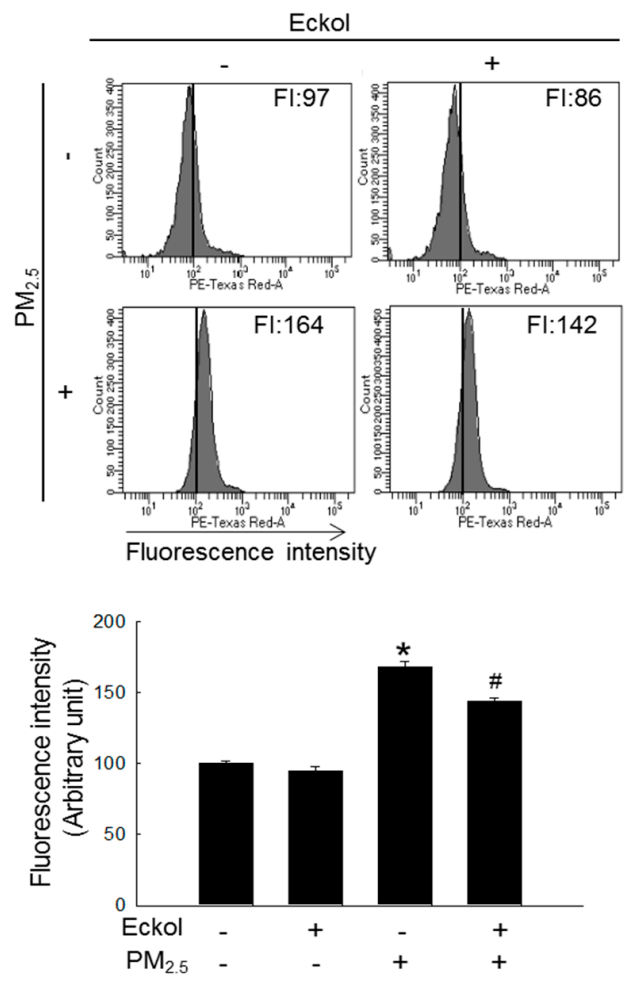

(e)

Figure 3. Eckol $(30 \mu \mathrm{M})$ prevented $\mathrm{PM}_{2.5}$-induced mitochondrial dysfunction by balancing mitochondrial membrane potential and calcium level. (a) Mitochondrial ROS induced by $\mathrm{PM}_{2.5}$ was decreased via treatment with eckol through DHR123 staining. Depolarization of mitochondrial membrane potential (JC-1 staining) induced by $\mathrm{PM}_{2.5}$ was repolarized via treatment with eckol through (b) flow cytometry and (c) confocal microscopy. Extra-mitochondrial $\mathrm{Ca}^{2+}$ (Rhod-2 AM staining) induced by $\mathrm{PM}_{2.5}$ was blocked by treatment with eckol was monitored using (d) confocal microscopy and (e) flow cytometry. All experiments were performed after treatment with $\mathrm{PM}_{2.5}$ for $24 \mathrm{~h}$, and $n=3$ for every group. ${ }^{*} p<0.05$ and ${ }^{\#} p<0.05$ compared to control cells and $\mathrm{PM}_{2.5}$-exposed cells, respectively. 


\subsection{Eckol Modulated $P M_{2.5}$-Induced Apoptotic Factors}

It has been reported that urban particulate pollution penetrates the skin barrier and causes apoptosis in keratinocytes by activating caspase-3 [22]. Therefore, we evaluated the levels of the proapoptotic protein-Bax, antiapoptotic protein-Bcl-2, and cleaved caspase-3 (Figure 4a). The protein levels of Bax and activated caspase-3 were increased by $\mathrm{PM}_{2.5}$, but expression of Bcl-2 was decreased by treatment with $\mathrm{PM}_{2.5}$. However, these were reversed by eckol treatment. To investigate whether $\mathrm{PM}_{2.5}$ could induce apoptosis, we counted apoptotic bodies via Hoechst 33342 dye staining (Figure $4 \mathrm{~b}$ ). The number of apoptotic cells in $\mathrm{PM}_{2.5}$ group surged four times compared to that in the control group. However, both eckol and Z-VAD-FMK (the caspase inhibitor) halted the apoptotic bodies induced by $\mathrm{PM}_{2.5}$.
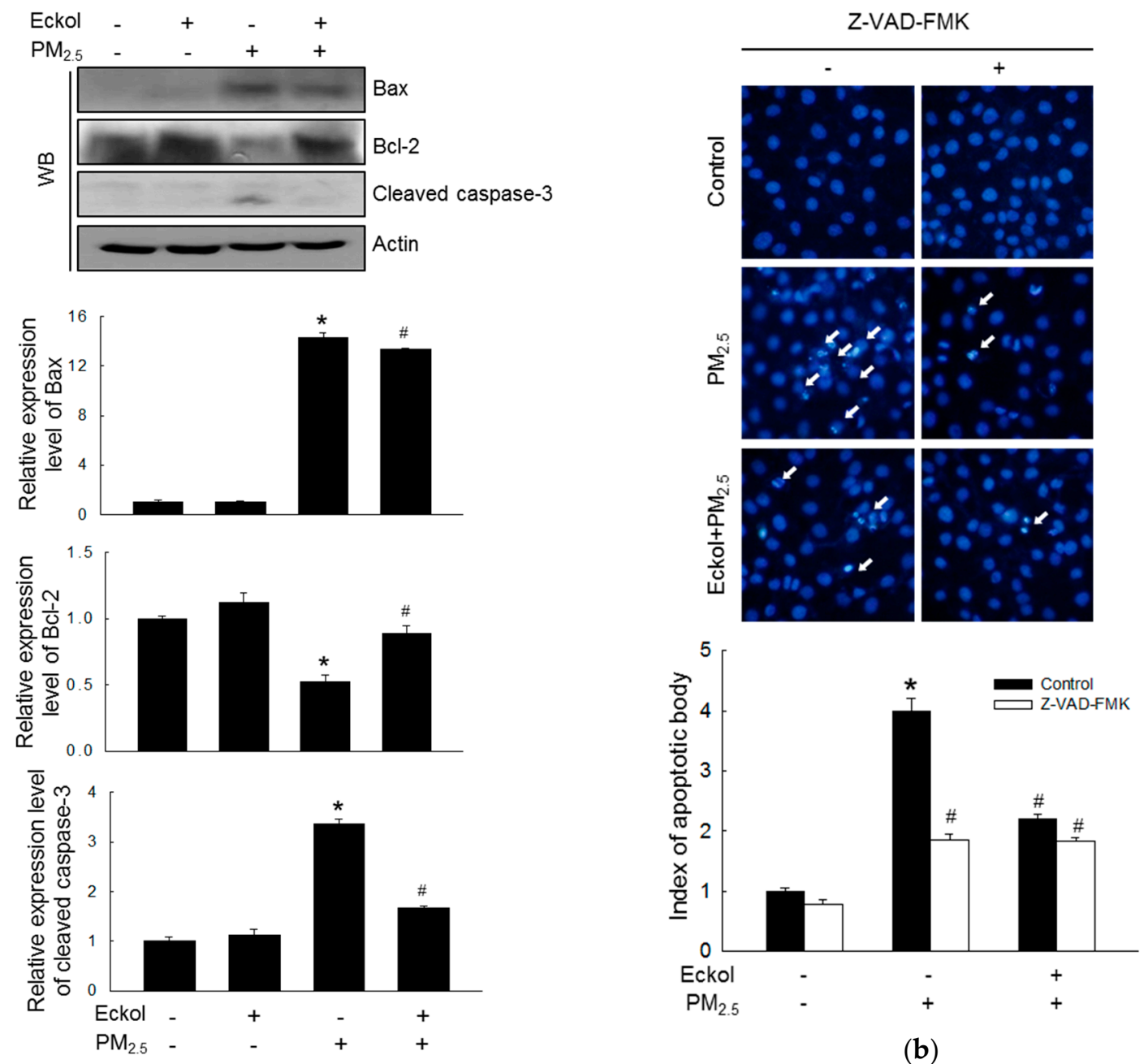

(b)

(a)

Figure 4. Eckol $(30 \mu \mathrm{M})$ regulated apoptosis-related proteins induced by $\mathrm{PM}_{2.5}$. (a) Increase of Bax and cleaved caspase- 3 and decrease of $\mathrm{Bcl}-2$ by $\mathrm{PM}_{2.5}$ were reversed by treatment with eckol, as observed by western blotting (WB). (b) Apoptosis induced by $\mathrm{PM}_{2.5}$ was reduced by treatment with eckol or caspase inhibitor (Z-VAD-FMK), as seen by Hoechst 33342 staining. All experiments were performed after treatment with $\mathrm{PM}_{2.5}$ for $24 \mathrm{~h}$, and $n=3$ for every group. ${ }^{*} p<0.05$ and ${ }^{\#} p<0.05$ compared to control cells and $\mathrm{PM}_{2.5}$-exposed cells, respectively.

\subsection{Eckol Reduced MAPK Signaling Pathway Activated by $P M_{2.5}$}

In a review, Sun et al. have pointed out that many anti-cancer therapeutics induced apoptosis by modulating the MAPK/ERK signaling pathway [23]. Thus, we checked the expression levels 
of MAPK-related proteins, ERK, p38, and JNK, and the results showed that $\mathrm{PM}_{2.5}$ could stimulate ERK, p38, and JNK (Figure 5a). However, eckol inhibited the activation of ERK, p38, and JNK. Next, we examined $\mathrm{PM}_{2.5}$-induced apoptotic bodies by treatment with MAPK pathway inhibitors, U0126, SB203580, and SP600125 (inhibitors of ERK, p38, and JNK, respectively), and the results showed that all these three inhibitors could reduce the number of apoptotic bodies (Figure $5 b$ ). In addition, eckol enhanced the anti-apoptotic effect of MAPK-related inhibitors.


(a)


Eckol+PM 2.5
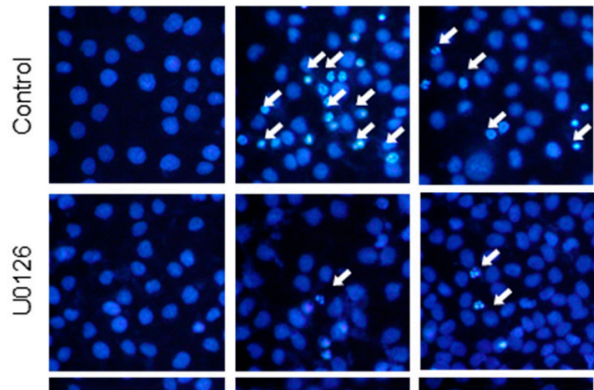

m
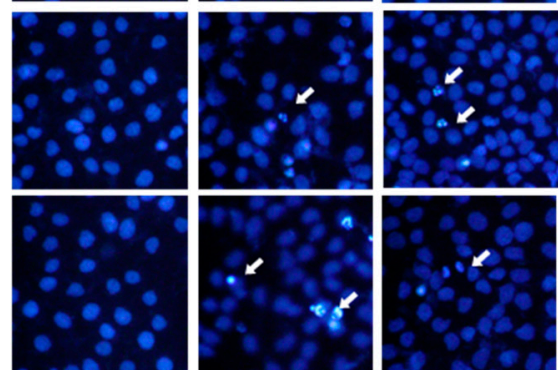

a
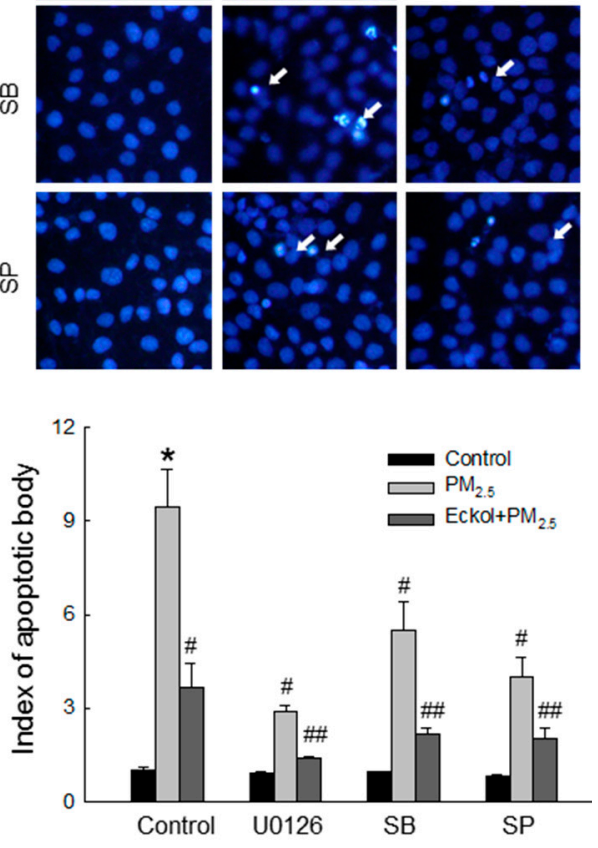

(b)

Figure 5. Eckol $(30 \mu \mathrm{M})$ reduced $\mathrm{PM}_{2.5}$-induced MAPK signaling pathway. (a) Western blot showing that activation of ERK, p38, and JNK induced by $\mathrm{PM}_{2.5}$ was reversed via treatment with eckol. (b) Apoptosis induced by $\mathrm{PM}_{2.5}$ was reduced by treatment with eckol or ERK, p38, and JNK inhibitors (U0126, SB203580 (SB), and SP600125 (SP), respectively), as observed through Hoechst 33342 staining. All experiments were performed after treatment with $\mathrm{PM}_{2.5}$ for $24 \mathrm{~h}$, and $n=3$ for every group. ${ }^{*} p<0.05,{ }^{\#} p<0.05$ and ${ }^{\# \#} p<0.05$ compared to control cells, $\mathrm{PM}_{2.5}$-exposed cells, and both inhibitor and $\mathrm{PM}_{2.5}$-exposed cells respectively.

\section{Discussion}

There have been several investigations into the bioactivities of eckol, since it was first isolated from Ecklonia cava [3]. Eckol has multi-protective effects towards several cell lines, including lung fibroblast cells [24], human dermal fibroblasts [8], Chang liver cells [25], and human keratinocytes [6]. Furthermore, eckol is a compound with therapeutic potential in many areas, such as anti-oxidative stress [24], radioprotective action [26], antithrombotic and profibrinolytic activities [27], and anticancer activity [28]. Piao et al. studied $\mathrm{PM}_{2.5}$-induced ROS generation at different concentrations $(25,50,75$, 
and $100 \mu \mathrm{g} / \mathrm{mL}$ ) for $24 \mathrm{~h}$ in HaCaT keratinocytes, and found that $\mathrm{PM}_{2.5} 50 \mu \mathrm{g} / \mathrm{mL}$ caused excessive ROS and skin dysfunction [29]. Usually, oxidative stress is caused by excessive accumulation of ROS or lack of the ability to eliminate them. $\mathrm{PM}_{2.5}$ produces large amounts of ROS beyond the clearance ability of cells [30]. In our study, eckol showed its ability to protect cells against $\mathrm{PM}_{2.5}$-induced ROS, cell cycle arrest, and apoptosis, and improved cell viability.

To explore the mechanism in detail, we checked the state of intracellular molecules such as lipids, protein, and DNA, which play various important roles in the cells [31]. Furthermore, intracellular macromolecular damage can be recognized as oxidative stress [32]. Our results demonstrated that $\mathrm{PM}_{2.5}$ indeed induced oxidation of molecules, whereas eckol relieved intracellular molecular damage. The review also points out that mitochondria-dependent ROS generation subsequently caused cell cycle arrest and apoptosis, which is ROS-mediated apoptosis via mitochondrial mechanism [33]. In addition, our previous studies showed that calcium level and mitochondrial membrane potential affect the function of mitochondria [30,34]. The data in Figure 3 show that $\mathrm{PM}_{2.5}$ increased the calcium level and depolarized mitochondrial membrane potential as compared to the control cells, whereas eckol regulated the mitochondria and maintained a stable state. The mechanism of mitochondrial damage is related to Bcl-2 proteins, which maintains mitochondrial membrane integrity [35]. The interaction between Bcl-2 and Bax also influences antiapoptosis [36]. Bcl-2 plays an anti-apoptotic role, whereas Bax is proapoptotic [37]. There is a complex crosslink between Bcl-2 family proteins and caspase proteins in cell apoptosis, in which Bcl-2 indirectly activates the caspase cascade [38]. The caspase- 3 results in apoptosis induced by both extrinsic and intrinsic stimulus [39]. The results elucidated that except for the decrease of Bcl-2, Bax and cleaved caspase-3 (activated caspase-3) were increased by $\mathrm{PM}_{2.5}$. However, eckol reversed these effects. Then, we treated cells with caspase inhibitor (Z-VAD-FMK) and found that upon pretreatment with caspase inhibitor, the apoptotic bodies were decreased significantly. These data prove that caspase proteins contributed to cell apoptosis induced by $\mathrm{PM}_{2.5}$. MAPK signaling pathway plays a role in many systems of cell proliferation, migration, and apoptosis [23]. Many drugs are used to modulate MAPK signaling pathway to induce cell apoptosis in cells, such as lung cancer [40], human colorectal cancer [41], and cervical cancer HeLa cells [42]. Finally, we checked MAPK signaling pathway-related proteins, ERK, p38, and JNK. The results show that $\mathrm{PM}_{2.5}$ activated all three proteins, but eckol exhibited the ability to inactivate them. When we used inhibitors of ERK, p38, and JNK to treat $\mathrm{PM}_{2.5}$-damaged cells, the numbers of apoptotic bodies were decreased, similar to eckol. These data further prove that MAPK signaling pathway plays a vital role in the inhibition of $\mathrm{PM}_{2.5}$-induced apoptosis by eckol.

Although the protective effects of eckol on human keratinocytes from $\mathrm{PM}_{2.5}$-induced skin damage has been shown, there are limitations to this study. These results from in vitro experiments need to be validated by animal studies and clinical trials. Moreover, the concentration of air pollutants in the natural environment is different from the $\mathrm{PM}_{2.5}$ purchased from the company, which provide certain ingredients for reference. In the future, there should be in vivo animal trials on skin protection to elucidate the protective effects and side effects of eckol under the complicated living environments.

\section{Materials and Methods}

\subsection{Eckol and $P M_{2.5}$}

Eckol was provided by Professor Nam Ho Lee of Jeju National University (Jeju, Korea), which belonged to Phaeophyceae. Preparation of the extract and its purification was following the reported protocol [43]. The dried brown alga Ecklonia cava was extracted with $80 \%$ methanol and the crude extract was purified by HPLC. After purification, $20 \mathrm{mg}$ of pure eckol was obtained from $1 \mathrm{~kg}$ dry weight of the brown algae. A stock solution of eckol was prepared by dimethyl sulfoxide (DMSO). The NIST particulate matter SRM 1650b ( $\mathrm{PM}_{2.5}$ ) was bought from Sigma-Aldrich (St. Louis, MO, USA) and a stock solution in DMSO was prepared to obtain a concentration of $\mathrm{PM}_{2.5}$ at $25 \mathrm{mg} / \mathrm{mL}$. DMSO was as the control. 


\subsection{Cell Culture}

The human HaCaT keratinocytes were purchased from Cell Lines Service (Heidelberg, Germany) and were grown in Dulbecco's modified Eagle's medium (Life Technologies Co., Grand Island, NY, USA) with $10 \%$ heat-inactivated fetal calf serum, streptomycin $(100 \mu \mathrm{g} / \mathrm{mL})$, and penicillin $(100 \mathrm{units} / \mathrm{mL})$. The cells were cultured at $37^{\circ} \mathrm{C}$ in an incubator in an atmosphere containing $5 \% \mathrm{CO}_{2}$ [6].

\subsection{ROS Detection}

To examine the intracellular ROS scavenging ability of eckol, DCF-DA (Sigma-Aldrich) staining assay was performed. Cells $\left(1.5 \times 10^{5}\right.$ cells/mL) were treated with eckol $(30 \mu \mathrm{M})$ for $30 \mathrm{~min}, \mathrm{PM}_{2.5}$ $(50 \mu \mathrm{g} / \mathrm{mL})$ for another $24 \mathrm{~h}$, and DCF-DA $(25 \mu \mathrm{M})$ sequentially. Then, the stained cells were detected by using a flow cytometer (Becton Dickinson, Franklin Lakes, NJ, USA) and confocal microscope (Carl Zeiss, Oberkochen, Germany). Similarly, mitochondrial ROS levels were detected by DHR123 (Molecular Probes) staining $(10 \mu \mathrm{M})$ [30].

\subsection{Sub-G $G_{1}$ Cell Detection}

Cells were treated with eckol $(30 \mu \mathrm{M})$ and $\mathrm{PM}_{2.5}(50 \mu \mathrm{g} / \mathrm{mL})$ sequentially. After $24 \mathrm{~h}$, cells were harvested and dyed with PI and RNase A (1:1000) for $30 \mathrm{~min}$. Finally, the fluorescence emission was detected with a FACSCalibur flow cytometer (Becton Dickinson) [30].

\subsection{Hoechst 33342 Staining}

The apoptotic bodies were examined with Hoechst 33342 (Sigma-Aldrich), which is a nucleus-specific dye. All cells were stained with Hoechst 33342, and the images were captured under a Cool SNAP-Pro color digital camera (Media Cybernetics, Silver Spring, MD, USA) in a fluorescence microscope [44].

\subsection{Cell Viability}

Cells were cultured with eckol and/or $\mathrm{PM}_{2.5}$ for $24 \mathrm{~h}$, and the dead cells were stained with $0.1 \%$ trypan blue solution. Then, unstained bodies (live cells) and stained bodies (dead cells) were counted separately. Cell viability (\%) was determined as: Live cells/ (live cells + dead cells) $\times 100 \%$ [45].

\subsection{Lipid Peroxidation Assay}

Cells $\left(1.5 \times 10^{5}\right.$ cells $\left./ \mathrm{mL}\right)$ were cultured with eckol and/or $\mathrm{PM}_{2.5}$ for $24 \mathrm{~h}$ in the chamber slides. The lipid hydroperoxides in cells were reacted with diphenylpyrenylphosphine (DPPP, Molecular Probes) and the lipid adducts of DPPP oxide were detected by a confocal microscope [30].

\subsection{Protein Carbonylation Assay}

Cells $\left(1.5 \times 10^{5}\right.$ cells $\left./ \mathrm{mL}\right)$ were cultured with eckol and/or $\mathrm{PM}_{2.5}$ for $24 \mathrm{~h}$ in the culture dish. The Oxiselect ${ }^{\mathrm{TM}}$ protein carbonyl ELISA kit (Cell Biolabs, San Diego, CA, USA) was used to detect protein oxidation following the manufacturer's instructions [34].

\subsection{Detection of 8-Oxoguanine (8-oxoG)}

Cells $\left(1.5 \times 10^{5}\right.$ cells $\left./ \mathrm{mL}\right)$ were cultured with eckol and/or $\mathrm{PM}_{2.5}$ for $24 \mathrm{~h}$ in the chamber slides. The avidin-TRITC conjugate was used to detect 8-oxoG, an indicator of oxidative DNA damage. The stained cells were visualized under a confocal microscope [27].

\subsection{Single Cell Gel Electrophoresis (Comet Assay)}

Cells $\left(1.5 \times 10^{5}\right.$ cells $\left./ \mathrm{mL}\right)$ were cultured with eckol and/or $\mathrm{PM}_{2.5}$ for $30 \mathrm{~min}$ in the microtubes, and the harvested cells were fixed on a microscopic slide with low-melting agarose (1\%). The slides 
with cells were permeated into lysis buffer ( $\mathrm{pH} 10)$ for $1 \mathrm{~h}$, which contained $\mathrm{NaCl}(2.5 \mathrm{M})$, Na-EDTA $(100 \mathrm{mM})$, Tris $(10 \mathrm{mM})$, Triton X-100 (1\%), and DMSO (10\%). Finally, the slides were subjected to electrophoresis, and the samples were dyed with ethidium bromide. The fluorescent images of the tails were captured with a fluorescence microscope and the tail lengths (50 cells per slide) were analyzed by the image analysis software (Kinetic Imaging, Komet 5.5, Liverpool, UK) [29].

\subsection{Quantification of $\mathrm{Ca}^{2+}$ Level}

Cells $\left(1.5 \times 10^{5}\right.$ cells $\left./ \mathrm{mL}\right)$ were cultured with eckol and/or $\mathrm{PM}_{2.5}$ for $24 \mathrm{~h}$ in the chamber slides. Cells were stained with Rhod-2 AM to check mitochondrial calcium levels, and the images were captured by confocal microscopy and flow cytometry [30].

\subsection{Mitochondrial Membrane Potential $(\Delta \Psi m)$ Analysis}

Cells $\left(1.5 \times 10^{5}\right.$ cells $\left./ \mathrm{mL}\right)$ were cultured with eckol and/or $\mathrm{PM}_{2.5}$ for $24 \mathrm{~h}$ in the chamber slides. Cells were stained with 5,5',6,6'-tetrachloro-1,1',3,3'-tetraethylbenzimidazolylcarbocyanine iodide (JC-1, Invitrogen, Carlsbad, CA, USA) to observe changes in cell membrane potential. The fluorescence emission was analyzed by confocal microscopy and flow cytometry [6].

\subsection{Western Blotting}

The protein lysates from harvested cells were subjected to SDS-PAGE and transferred into membranes in sequence. The membranes were incubated with primary and secondary antibody (Pierce, Rockford, IL, USA) for $1 \mathrm{~h}$ separately. Protein bands were visualized via X-ray film (AGFA, Belgium). The following primary antibodies were used: caspase-3, phospho-p38, phospho-ERK, and phospho-JNK (Cell Signaling Technology, Beverly, MA, USA), Bax and Bcl-2 (Santa Cruz Biotechnology, Santa Cruz, CA, USA), and actin (Sigma-Aldrich) [44].

\subsection{Statistical Analysis}

All data were collected from three experiments and presented as mean \pm standard error, which were analyzed by variance (ANOVA) with Tukey's test using Sigma Stat (v12) software (SPSS, Chicago, IL, USA). $P$-values $<0.05$ were considered statistically significant.

\section{Conclusions}

$\mathrm{PM}_{2.5}$ causes skin cell damage by generating ROS, excess of which oxidizes intracellular molecules and causes mitochondrial dysfunction, and activates MAPK signaling pathways. The skin is the first protection from various pollutants in the air, and it is important to identify effective biological compounds to prevent skin damage. Eckol has been known to inhibit UVB-induced ROS generation in keratinocytes [6]. In this study, we show that eckol could protect keratinocytes from $\mathrm{PM}_{2.5}$-induced apoptosis by halting ROS generation, suggesting that eckol is a suitable candidate for skin protection and can be useful in the cosmetics industry as well as in medicine.

Author Contributions: A.X.Z., Y.J.H. and J.W.H. designed the experiments and wrote the paper; A.X.Z., M.J.P., K.A.K. and P.D.; S.M.F. performed the experiments; M.J.A., J.M.Y., H.K.K., Y.S.K. and N.H.L. contributed to the analytical tools.

Funding: This work was supported by a grant from the Basic Research Laboratory Program (NRF-2017R1A4A1014512) by the National Research Foundation of Korea (NRF) grant funded by the Korea government (MSIP).

Conflicts of Interest: The authors declare no conflict of interest. 


\section{References}

1. Heo, S.J.; Ko, S.C.; Cha, S.H.; Kang, D.H.; Park, H.S.; Choi, Y.U.; Kim, D.; Jung, W.K.; Jeon, Y.J. Effect of phlorotannins isolated from Ecklonia cava on melanogenesis and their protective effect against photo-oxidative stress induced by UV-B radiation. Toxicol. In Vitro 2009, 23, 1123-1130. [CrossRef] [PubMed]

2. Kong, C.S.; Kim, J.A.; Ahn, B.N.; Kim, S.K. Potential effect of phloroglucinol derivatives from Ecklonia cava on matrix metalloproteinase expression and the inflammatory profile in lipopolysaccharide-stimulated human THP-1 macrophages. Fish. Sci. 2011, 77, 867-873. [CrossRef]

3. Ko, S.C.; Cha, S.H.; Heo, S.J.; Lee, S.H.; Kang, S.M.; Jeon, Y.J. Protective effect of Ecklonia cava on UVB-induced oxidative stress: In Vitro and In Vivo zebrafish model. J. Appl. Phycol. 2011, 23, 697-708. [CrossRef]

4. Sanjeewa, K.K.A.; Kim, E.A.; Son, K.T.; Jeon, Y.J. Bioactive properties and potential cosmeceutical applications of phlorotannins isolated from brown seaweeds: A review. J. Photochem. Photobiol. B 2016, 162, $100-105$. [CrossRef] [PubMed]

5. Muhammad, K.; Mohamed, S. Ethanolic extract of Eucheuma cottonii promotes in vivo hair growth and wound healing. J. Anim. Vet. Adv. 2011, 10, 601-605.

6. Piao, M.J.; Lee, N.H.; Chae, S.; Hyun, J.W. Eckol inhibits ultraviolet B-induced cell damage in human keratinocytes via a decrease in oxidative stress. Biol. Pharm. Bull. 2012, 35, 873-880. [CrossRef] [PubMed]

7. Hwang, H.; Chen, T.; Nines, R.G.; Shin, H.C.; Stoner, G.D. Photochemoprevention of UVB-induced skin carcinogenesis in SKH-1 mice by brown algae polyphenols. Int. J. Cancer 2006, 119, 2742-2749. [CrossRef] [PubMed]

8. Joe, M.J.; Kim, S.N.; Choi, H.Y.; Shin, W.S.; Park, G.M.; Kang, D.W.; Kim, Y.K. The inhibitory effects of eckol and dieckol from Ecklonia stolonifera on the expression of matrix metalloproteinase-1 in human dermal fibroblasts. Biol. Pharm. Bull. 2006, 29, 1735-1739. [CrossRef] [PubMed]

9. Kim, K.H.; Jahan, S.A.; Kabir, E. A review on human health perspective of air pollution with respect to allergies and asthma. Environ. Int. 2013, 59, 41-52. [CrossRef]

10. Ngoc, L.; Park, D.; Lee, Y.; Lee, Y.C. Systematic review and meta-analysis of human skin diseases due to particulate matter. Int. J. Environ. Res. Public Health 2017, 14, 1458. [CrossRef]

11. Guaita, R.; Pichiule, M.; Mate, T.; Linares, C.; Diaz, J. Short-term impact of particulate matter (PM2.5) on respiratory mortality in Madrid. Int. J. Environ. Health Res. 2011, 21, 260-274. [CrossRef] [PubMed]

12. Halonen, J.I.; Lanki, T.; Tuomi, T.Y.; Tiittanen, P.; Kulmala, M.; Pekkanen, J. Particulate air pollution and acute cardiorespiratory hospital admissions and mortality among the elderly. Epidemiology 2009, 20, 143-153. [CrossRef] [PubMed]

13. Perez, L.; Tobías, A.; Querol, X.; Pey, J.; Alastuey, A. Saharan dust, particulate matter and cause-specific mortality: A case-crossover study in Barcelona (Spain). Environ. Int. 2012, 48, 150-155. [CrossRef] [PubMed]

14. Atkinson, R.W.; Fuller, G.W.; Anderson, H.R.; Harrison, R.M.; Armstrong, B. Urban ambient particle metrics and health: A time series analysis. Epidemiology 2010, 21, 501-511. [CrossRef] [PubMed]

15. Kim, K.H.; Kabir, E.; Kabir, S. A review on the human health impact of airborne particulate matter. Environ. Int. 2015, 74, 136-143. [CrossRef] [PubMed]

16. Kim, K.E.; Cho, D.; Park, H.J. Air pollution and skin diseases: Adverse effects of airborne particulate matter on various skin diseases. Life Sci. 2016, 152, 126-134. [CrossRef] [PubMed]

17. Manandhar, B.; Paudel, P.; Seong, S.H.; Jung, H.A.; Choi, J.S. Characterizing eckol as a therapeutic aid: A systematic review. Mar. Drugs 2019, 17, 361. [CrossRef]

18. Kang, N.J.; Koo, D.H.; Kang, G.J.; Han, S.C.; Lee, B.W.; Koh, Y.S.; Hyun, J.W.; Lee, N.H.; Ko, M.H.; Kang, H.K.; et al. Dieckol, a component of Ecklonia cava, suppresses the production of MDC/CCL22 via down-regulating STAT1 pathway in interferon- $\gamma$ stimulated HaCaT human keratinocytes. Biomol. Ther. (Seoul) 2015, 23, 238-244.

19. Hyun, Y.J.; Piao, M.J.; Kang, K.A.; Zhen, A.X.; Madushan Fernando, P.D.S.; Kang, H.K.; Ahn, Y.S.; Hyun, J.W. Effect of fermented fish oil on fine particulate matter-induced skin aging. Mar. Drugs 2019, 17, 61. [CrossRef]

20. Ghosh, D.; LeVault, K.R.; Barnett, A.J.; Brewer, G.J. A reversible early oxidized redox state that precedes macromolecular ROS damage in aging nontransgenic and 3xTg-AD mouse neurons. J. Neurosci. 2012, 32, 5821-5832. [CrossRef] 
21. Shin, E.J.; Tran, H.Q.; Nguyen, P.T.; Jeong, J.H.; Nah, S.Y.; Jang, C.G.; Nabeshima, T.; Kim, H.C. Role of mitochondria in methamphetamine-induced dopaminergic neurotoxicity: Involvement in oxidative stress, Neuroinflammation, and pro-apoptosis-a review. Neurochem. Res. 2017, 43, 57-69. [CrossRef] [PubMed]

22. Pan, T.L.; Wang, P.W.; Aljuffali, I.A.; Huang, C.T.; Lee, C.W.; Fang, J.Y. The impact of urban particulate pollution on skin barrier function and the subsequent drug absorption. J. Dermatol. Sci. 2015, 78, 51-60. [CrossRef] [PubMed]

23. Sun, Y.; Liu, W.Z.; Liu, T.; Feng, X.; Yang, N.; Zhou, H.F. Signaling pathway of MAPK/ERK in cell proliferation, differentiation, migration, senescence and apoptosis. J. Recept. Signal Transduct. Res. 2015, 35, 600-604. [CrossRef] [PubMed]

24. Kang, K.A.; Lee, K.H.; Chae, S.; Zhang, R.; Jung, M.S.; Lee, Y.; Kim, S.Y.; Kim, H.S.; Joo, H.G.; Park, J.W.; et al. Eckol isolated from Ecklonia cava attenuates oxidative stress induced cell damage in lung fibroblast cells. FEBS Lett. 2005, 579, 6295-6304. [CrossRef] [PubMed]

25. Kim, A.D.; Kang, K.A.; Piao, M.J.; Kim, K.C.; Zheng, J.; Yao, C.W.; Cha, J.W.; Hyun, C.L.; Kang, H.K.; Lee, N.H.; et al. Cytoprotective effect of eckol against oxidative stress-induced mitochondrial dysfunction: Involvement of the FoxO3a/AMPK pathway. J. Cell. Biochem. 2014, 115, 1403-1411. [CrossRef] [PubMed]

26. Park, E.; Ahn, G.N.; Lee, N.H.; Kim, J.M.; Yun, J.S.; Hyun, J.W.; Jeon, Y.J.; Wie, M.B.; Lee, Y.J.; Park, J.W.; et al. Radioprotective properties of eckol against ionizing radiation in mice. FEBS Lett. 2008, 582, 925-930. [CrossRef] [PubMed]

27. Kim, T.H.; Ku, S.K.; Bae, J.S. Antithrombotic and profibrinolytic activities of eckol and dieckol. J. Cell. Biochem. 2012, 113, 2877-2883. [CrossRef] [PubMed]

28. Hyun, K.H.; Yoon, C.H.; Kim, R.K.; Lim, E.J.; An, S.; Park, M.J.; Hyun, J.W.; Suh, Y.; Kim, M.J.; Lee, S.J. Eckol suppresses maintenance of stemness and malignancies in glioma stem-like cells. Toxicol. Appl. Pharmacol. 2011, 254, 32-40. [CrossRef] [PubMed]

29. Piao, M.J.; Ahn, M.J.; Kang, K.A.; Ryu, Y.S.; Hyun, Y.; Shilnikova, K.; Zhen, A.X.; Jeong, J.W.; Choi, Y.H.; Kang, H.K.; et al. Particulate matter 2.5 damages skin cells by inducing oxidative stress, subcellular organelle dysfunction, and apoptosis. Arch. Toxicol. 2018, 92, 2077-2091. [CrossRef] [PubMed]

30. Zhen, A.X.; Piao, M.J.; Hyun, Y.J.; Kang, K.A.; Madushan Fernando, P.D.S.; Cho, S.J.; Ahn, M.J.; Hyun, J.W. Diphlorethohydroxycarmalol attenuates fine particulate matter-induced subcellular skin dysfunction. Mar. Drugs 2019, 17, 95. [CrossRef] [PubMed]

31. Jorge, A.T.; Arroteia, K.F.; Lago, J.C.; de Sa-Rocha, V.M.; Gesztesi, J.; Moreira, P.L. A new potent natural antioxidant mixture provides global protection against oxidative skin cell damage. Int. J. Cosmet. Sci. 2011, 33, 113-119. [CrossRef] [PubMed]

32. Trachana, V.; Petrakis, S.; Fotiadis, Z.; Siska, E.K.; Balis, V.; Gonos, E.S.; Kaloyianni, M.; Koliakos, G. Human mesenchymal stem cells with enhanced telomerase activity acquire resistance against oxidative stress-induced genomic damage. Cytotherapy 2017, 19, 808-820. [CrossRef] [PubMed]

33. Kiang, J.G.; Olabisi, A.O. Radiation: A poly-traumatic hit leading to multi-organ injury. Cell Biosci. 2019, 9, 25. [CrossRef] [PubMed]

34. Zhen, A.X.; Piao, M.J.; Hyun, Y.J.; Kang, K.A.; Ryu, Y.S.; Cho, S.J.; Kang, H.K.; Koh, Y.S.; Ahn, M.J.; Kim, T.H.; et al. Purpurogallin protects keratinocytes from damage and apoptosis induced by Ultraviolet B radiation and particulate matter 2.5. Biomol. Ther. 2019, 27, 395-403. [CrossRef] [PubMed]

35. Zheng, J.H.; Viacava Follis, A.; Kriwacki, R.W.; Moldoveanu, T. Discoveries and controversies in BCL-2 protein-mediated apoptosis. FEBS J. 2016, 283, 2690-2700. [CrossRef] [PubMed]

36. Moldoveanu, T.; Follis, A.V.; Kriwacki, R.W.; Green, D.R. Many players in BCL-2 family affairs. Trends Biochem. Sci. 2014, 39, 101-111. [CrossRef] [PubMed]

37. Czabotar, P.E.; Lessene, G.; Strasser, A.; Adams, J.M. Control of apoptosis by the BCL-2 protein family: Implications for physiology and therapy. Nat. Rev. Mol. Cell Biol. 2014, 15, 49-63. [CrossRef]

38. Elmore, S. Apoptosis: A review of programmed cell death. Toxicol. Pathol. 2007, 35, 495-516. [CrossRef]

39. Asweto, C.O.; Wu, J.; Alzain, M.A.; Hu, H.; Andrea, S.; Feng, L.; Yang, X.; Duan, J.; Sun, Z. Cellular pathways involved in silica nanoparticles induced apoptosis: A systematic review of In Vitro studies. Environ. Toxicol. Pharmacol. 2017, 56, 191-197. [CrossRef]

40. Jeanson, A.; Boyer, A.; Greillier, L.; Tomasini, P.; Barlesi, F. Therapeutic potential of trametinib to inhibit the mutagenesis by inactivating the protein kinase pathway in non-small cell lung cancer. Expert Rev. Anticancer Ther. 2018, 4, 1-7. [CrossRef] 
41. Pan, H.; Wang, Y.; Na, K.; Wang, Y.; Wang, L.; Li, Z.; Guo, C.; Guo, D.; Wang, X. Autophagic flux disruption contributes to Ganoderma lucidum polysaccharide-induced apoptosis in human colorectal cancer cells via MAPK/ERK activation. Cell Death Dis. 2019, 10, 456. [CrossRef] [PubMed]

42. Yao, W.; Lin, Z.; Wang, G.; Li, S.; Chen, B.; Sui, Y.; Huang, J.; Liu, Q.; Shi, P.; Lin, X.; et al. Delicaflavone induces apoptosis via mitochondrial pathway accompanying G2/M cycle arrest and inhibition of MAPK signaling cascades in cervical cancer HeLa cells. Phytomedicine 2019, 62, 152973. [CrossRef] [PubMed]

43. Moon, C.; Kim, S.H.; Kim, J.C.; Hyun, J.W.; Lee, N.H.; Park, J.W.; Shin, T. Protective effect of phlorotannin components phloroglucinol and eckol on radiation-induced intestinal injury in mice. Phytother. Res. 2008, 22, 238-242. [CrossRef] [PubMed]

44. Han, X.; Kang, K.A.; Piao, M.J.; Zhen, A.X.; Hyun, Y.J.; Kim, H.M.; Ryu, Y.S.; Hyun, J.W. Shikonin exerts cytotoxic effects in human colon cancers by inducing apoptotic cell death via the endoplasmic reticulum and mitochondria-mediated pathways. Biomol. Ther. 2019, 27, 41-47. [CrossRef] [PubMed]

45. Kim, D.Y.; Kim, J.H.; Lee, J.C.; Won, M.H.; Yang, S.R.; Kim, H.C.; Wie, M.B. Zinc oxide nanoparticles exhibit both cyclooxygenase- and lipoxygenase-mediated apoptosis in human bone marrow-derived mesenchymal stem cells. Toxicol. Res. 2019, 35, 83-91. [CrossRef] [PubMed]

(C) 2019 by the authors. Licensee MDPI, Basel, Switzerland. This article is an open access article distributed under the terms and conditions of the Creative Commons Attribution (CC BY) license (http://creativecommons.org/licenses/by/4.0/). 